\title{
Probiotics and oral-periodontal health
}

\author{
Mahmet C Haytac ${ }^{1}$, Anatoly A Kunin ${ }^{2 *}$, Irina A Belenova ${ }^{2 \dagger}$ \\ From EPMA-World Congress 2013 \\ Brussels, Belgium. 20-21 September 2013
}

Periodontitis is a chronic inflammatory disease culminating in loss of periodontal support structures. The etiology of this destructive disease is primarily related to biofilm formation with certain putative bacterial pathogens. The development of antibiotics resistance by certain important pathogens has increased the possibility of returning to the pre-antibiotic age. During last decade, identification of health-associated and potentially beneficial bacterial species that may reside in the gingival sulcus and oral cavity has been the topic of numerous studies focused on prevention and treatment of certain diseases. Probiotics are live microorganisms (in most cases, bacteria) that are similar to beneficial microorganisms found in the human gastrointestinal tract. They are also called "friendly bacteria" or "good bacteria". Commonly, most of the species ascribed as having probiotic properties belong to the genera Lactobacillus and Bifidobacterium. Use of probiotics to maintain oral or periodontal health can provide a natural defense against bacteria, which are thought to be harmful to teeth and gums. Thus, identification of useful probiotics and establishing the most appropriate dose and vehicle for their use are areas of active investigation. While, dairy products have been most investigated, other means of probiotics use such as those in chewing gums or lozenges have also been studied. Although probiotics are in the initial stages of scientific research and application, they offer a natural and promising therapeutic approach. Accordingly, we will discuss latest research data on probiotics use for prevention and treatment of oral and periodontal diseases.

\section{Authors' details}

${ }^{1}$ Professor, Cukurova University, Faculty of Dentistry, Turkey. ${ }^{2}$ Professors, Dr. Med. Sc., Voronezh N.N. Burdenko State Medical Academy, Therapeutic Dentistry Department, Voronezh, Russia.

\footnotetext{
* Correspondence: kunin36@gmail.com

† Contributed equally

${ }^{2}$ Professors, Dr. Med. Sc., Voronezh N.N. Burdenko State Medical Academy,

Therapeutic Dentistry Department, Voronezh, Russia

Full list of author information is available at the end of the article
}

Published: 11 February 2014

doi:10.1186/1878-5085-5-S1-A125

Cite this article as: Haytac et al:: Probiotics and oral-periodontal health.

EPMA Journal 2014 5(Suppl 1):A125.
Submit your next manuscript to BioMed Central and take full advantage of:

- Convenient online submission

- Thorough peer review

- No space constraints or color figure charges

- Immediate publication on acceptance

- Inclusion in PubMed, CAS, Scopus and Google Scholar

- Research which is freely available for redistribution

Submit your manuscript at www.biomedcentral.com/submit

\section{Ciomed Central}

